\title{
Conceptualising Modes of Redistribution in Public Urban Infrastructure
}

\begin{abstract}
In this paper, we distinguish between five modes of redistribution in the allocation of funding for public urban infrastructure, including: the prioritisation of disadvantaged urban areas (area-based redistribution); the prioritisation of infrastructures that support disadvantaged populations (differentiated redistribution); reorganisation of urban infrastructural networks to address issues such as centralisation (systemic redistribution); transformation of infrastructure funding allocation and delivery systems (structural redistribution); and the prioritisation of infrastructures that support a convivial urban culture (relational redistribution). We apply the first three modes of redistribution with a longitudinal comparative analysis of state government infrastructure expenditure in Sydney and Melbourne, Australia, from 1999/2000 to 2015/16. This analysis shows that infrastructure expenditure in Melbourne represented a more just approach to redistribution, in an areabased, differentiated and systemic sense. It highlights the potential and limitations of each mode of analysing redistribution, and their combined application as a lens into spatial justice.
\end{abstract}

Keywords: Just City; Spatial Justice; Distributive justice; Redistribution; Infrastructure; Recognition; Conviviality.

Redistribution has been a key tenet of debates about the just city and spatial justice (Soja, 2000; Marcuse, 2009). Redistribution is considered a more just approach to allocation of valued social resources, with the objective to "produce equitable outcomes rather than support those already well off" (Fainstein, 2010, p. 16). In spatial terms, an urban redistributive agenda seeks to reduce inequalities "by promoting urban spatial arrangements which do not disadvantage some people relative to others" (Fincher and Iveson, 2008, p. 24). In urban studies, discussions on redistribution have often focused on infrastructure. While often immobilized in space, urban infrastructures such as energy, transport, water, sewerage, and communication networks enable the mobilities and circulations of the city. When they function undisrupted, infrastructures are taken for granted, hidden in the background of 
everyday lives, and yet they are essential to the existence of modern urban life (Graham, 2010). The uneven spatial distribution of urban infrastructure produces inequalities, from access to material resources (Harvey, 1973), to people's ability to develop capabilities and conduct activities they value (Pereira et al., 2017).

In the mid-twentieth century, redistribution was central to mainstream urban policy, supported by both Keynsian-Fordist economics, and a Rawlsian ethic of distributive justice. Since the 1970s, the redistribution agenda has been overridden by neoliberal urban politics. As argued by DeFillipis (2009, p. 156), "the Keynesian city as a social process is now behind us, and the state has now removed itself from much of its social redistribution role". Opposition to neoliberalism has seen a resurgence in urban justice activism and scholarship, reasserting the need for redistribution. However, it is not necessarily the Ralwsian-KeynsianFordist model of redistribution that some justice theorists and activists seek to reinstall. Indeed, many have been sceptical of liberal conceptions of redistribution for their overly material rather than relational approach to inequality (Young, 1990), for their universalist blindness to social differences such as race, gender and ability (Fincher and Iveson, 2008; Mills, 2013), and for their failure to transform the underlying social and economic relations that give rise to inequality (Harvey, 1973; Fraser, 1995).

Attentive to such critiques, in this paper we offer a classification of five modes of redistribution in public urban infrastructure. We address differences in access to resources from different urban areas (area-based redistribution) as our starting point, but also transcend the limitations of such analysis by attending to the differential effects of infrastructural priorities on diverse people (differentiated redistribution); acknowledging the operation of urban infrastructures as interconnected networks rather than isolated "bundles" (systemic redistribution); addressing the systems of allocation and delivery that produce unequal distributive patterns (structural redistribution); and, considering how infrastructures can support or inhibit a convivial urban culture (relational redistribution).

We examine the relations between different modes of redistribution, by applying three of the five modes to analyse patterns of state government infrastructure expenditure in Sydney and Melbourne, Australia, from 1999/2000 to 2015/2016. This analysis suggests expenditure in Melbourne represents a more just approach to redistribution, in terms of the locations which are prioritised (area-based redistribution), the types of infrastructures that are prioritised 


\section{The Rise and Demise of Spatial Redistribution}

Redistribution was a critical component of the economic paradigm which dominated developed countries in the mid-twentieth century, pursued through a variety of state-led interventions, including progressive taxation and increased investment in public infrastructures and social-welfare programmes (Fraser, 1995). From a Fordist-Keynesian economic perspective, the costs of redistribution were expected to be offset by its boost to mass production, distribution and consumption, as well as its counter-cyclical potential (Jessop, 2002, p. 77; Bowles and Fong, 2012, p. 1). From an ethical perspective, Rawls (1971) upheld redistribution as the foundation of social justice. For Rawls, uneven distribution of resources is just when it benefits those who are least well-off, while also producing aggregate benefits that are to everyone's advantage.

In urban studies, the Rawlsian-Fordist-Keynesian approach to redistribution was articulated through analyses of equity in the spatial distribution of socially valued resources as well as harmful externalities (e.g. pollution) (Levy et al. 1974; Dear, 1992). This liberal formulation of redistributive spatial justice approach stems from a view of the city as a "gigantic resource system" (Harvey, 1973, p. 68), where inhabitants' "real income" is determined not only by their wage or social security payments, but also their geographic location. To remedy inequalities in real income, redistribution policies prioritise areas perceived as disadvantaged in the allocation of valued resources, while also applying fair-share principles to the allocation of externalities.

Marxist and feminist theorists were particularly critical of liberal framings of redistribution, which reinforce rather than contest unequal social relations. From a Marxist perspective, "programmes which seek to alter distribution without altering the capitalist market structure within which income and wealth are generated and distributed, are doomed to failure" 
(Harvey 1973, p. 110). For Harvey, public infrastructure investment - whether in poor or wealthy areas - serves the function of a capitalist economy and benefits the elites who control it. For example, procurement of private companies to plan, build and manage public infrastructures can be understood as an indirect public subsidy for elites. In this context, even the know-how of redistributive planning becomes a commodity largely controlled by elites (Roberts and Catungal, 2017).

From a feminist perspective, for Iris Marion Young (1990), both the Rawlsian conception of distributive justice and the Marxist response to it, are flawed in their narrow materialism. Human beings are understood exclusively as possessors and consumers of goods rather than relational beings, for whom a good life is also about "learning and using satisfying and expansive skills in socially recognized settings; participating in forming and running institutions, and receiving recognition for such participation; playing and communicating with others, and expressing our experience, feelings, and perspective on social life in contexts where others can listen" (Young, 1990, p. 37). Hence, for Young, a theory of social justice must be conceived in relational terms, focusing on oppression and domination rather than material possessions. However, as pointed out by Pereira et al. (2017), the distribution of material resources, such as infrastructures, shapes people capabilities to participate in activities and relations they value (Pereira et al., 2017).

Indeed, seeking to address both the material and relational dimensions of inequality, Nancy Fraser (1995) grouped injustice and its remedies in two overarching categories redistribution and recognition - and emphasised the inherent tension between them. Fraser argued that claims for recognition call for group differentiation, while claims for redistribution often seek to eliminate such differences. Fraser further distinguished between affirmative and transformative approaches to redistribution. Affirmative measures leave intact the underlying political-economic structure that gives rise to unequal distribution in the first place. Affirmative redistributive measures can be harmful when they reinforce the stigmatisation of recipients "as inherently deficient and insatiable, as always needing more and more" (Fraser, 1995, p. 85).

The 1990s debate between Young and Fraser, and the foundational concepts arising from it, continue to inform contemporary debates about cities, justice and redistribution (Iveson et al., 2018). However, since the 1970s, the shift from Keynesian to neoliberal economics in many developed countries saw a retraction of the redistributive paradigm in the name of "small 


\section{Five modes of redistribution: a critical classification}

As asserted by Enright (2019, p. 668), while liberal theorisations of distributive justice are useful for identifying the criteria of harm and benefits, they are limited "in accounting for more complex, dynamic, and systematic entanglements" through which urban space is produced. Indeed, in this section we propose a new classification of five modes of redistribution (Table 1), that builds on liberal conceptions as our starting point, but transcends beyond it to incorporate more critical understanding of spatial justice in cities. Our classification is focused on the distribution of public urban infrastructures and services, from childcare centres, parks and neighbourhood houses, through to roads, public transport stations and sewage and treatment facilities. This classification would not fully apply to other mechanisms of redistribution, such as progressive taxation and social security benefits, which involve different spatial dynamics.

Area-based redistribution is concerned with measuring the full "bundle" of services and externalities accessible from different urban areas, which in turn are understood as physically bounded containers of goods and harms (Fincher and Iveson, 2008, p. 34). An area with a rich bundle of infrastructures such as childcare, education, health and transport facilities is understood as benefiting from locational advantage. An area lacking in these kinds of facilities, or one negatively affected by proximity to externalities such as an environmental health hazard, is understood as experiencing locational disadvantage. The primary limitation of area-based redistribution is the implicit presumption that the benefits and costs of proximity to social goods and externalities are equal for every person. For instance, investment in adequate infrastructure in an urban area might be beneficial to local homeowners, while also harmful to low-income renters by promoting gentrification and displacement.

Differentiated redistribution, in contrast, assumes that the benefits and harms of any infrastructure are highly differentiated by class, gender, race, ability and other social differences, as asserted by critics of universalist distributive justice (e.g. Mills, 2013). Rather 
than equal treatment for all, the goal of differentiated redistribution is to provide “differentiated supports to individuals and populations" (Enright, 2019). Differentiated redistribution involves the prioritisation of services and infrastructures that benefit less privileged social groups, such as child care services provision, which recognises the needs of women working in the paid labour force (Fincher and Iveson, 2008, p. 49). Empirically, understanding patterns of differentiated redistribution requires multiple methods of analysis, firstly, to establish the types of infrastructures that are being prioritised; and secondly, to evaluate how different populations access and use different types of infrastructure, and what benefits and harms they consequently experience.

Systemic redistribution is premised on an understanding of urban infrastructures as a complex networked system (Graham and Marvin, 2002, pp. 46-7), as opposed to independent "area bundles". Rather than spatial proximity to facilities from any given area, systemic redistribution is focused on other effects associated with the systemic organisation of a city's infrastructure network, such as its level of centralisation or integration across different types of infrastructure. Whereas neoliberal ideologies that frame cities as primarily economic systems are focused on the productivity effects of different network configurations, systemic redistribution is focused on the spatial justice of effects of such configurations. For example, disproportionate investment in infrastructure and facilities in the metropolitan centre produces a centralised infrastructure network, with unequal effects beyond the obvious advantages for those living close to the city. For instance, centralised investment reinforces the spatial separation between the private (suburban homes) and public (workplaces) spheres, which feminist critics have associated with gender inequality. It is not only geographical distance from the infrastructure rich city centre that harms women (since this equally affects men), rather the symbolic and physical design of a city divided into private and public spheres that reproduces the unequal sexual division of labour (Hayden, 1980; Sandercock and Forsyth, 1992, p. 50).

Structural redistribution concerns the question of who controls the production of urban space, as a Right to the City (Lefebvre, 1968). Structural redistribution seeks to transform the institutions overseeing the planning, funding and delivery of urban infrastructures and services, to produce more equitable distributive outcomes. Structural redistribution may occur as part of a wider, wholesale societal and political transformation such as a shift from capitalism to socialism (as per Fraser's [1995] notion of transformative redistribution). At a more affirmative level, structural redistribution might also involve more localised changes to 
[Insert Table 1 here]

resource allocation and delivery systems. For example, this might involve a turn from privatised or semi-privatised provision of publicly-funded infrastructures, towards their delivery as cooperatives or through social procurement methods, such as employment of, or ownership by, marginalized populations (McCrudden, 2004). Likewise, Participatory Budgeting involves transformation of decision-making systems in funding allocation. The extent to which participatory budgeting is transformative or affirmative is open to debate (Davidson, 2018).

Finally, relational redistribution, rather than material advantages or disadvantages for any particular "social group", is focused on how infrastructures shape social relations. Relational redistribution therefore involves prioritisation of infrastructures that promote more convivial social relations, such as neighbourhood drop-in centres and public libraries that are known to as providing a safe and inclusive environment where different people can meet and engage in convivial encounter (Fincher and Iveson, 2008, p. 161). Over time across the city, these seemingly mundane encounters can be transformative in building a convivial urban culture (Gilroy, 2006). Analysis of relational distribution can focus on measuring the extent to which facilities already known for their convivial potential are prioritised; and, on identifying new types, or new forms of delivery, of infrastructures that can promote urban conviviality.

Operationalising each of the five modes of redistribution requires different modes of analysis, drawing on different types and sources of data. While not every study can comprehensively address all five, but the framework is useful in highlighting the contributions but also limitations of each study and the modes of analysis it applies. Indeed, in the following sections we apply the analytical framework proposed above in a longitudinal comparative analysis of infrastructure expenditure patterns in Melbourne and Sydney. The data available to us - historical records of state government expenditure on infrastructure projects - was conducive to analysis of distributive outcomes through the area-based, differentiated and systemic lenses. Analysis of structural and relational modes of redistribution, requires indepth qualitative data on the process through which funding allocation decisions are made and executed, and on the effects of these infrastructure on everyday social relations. 


\section{Method}

State infrastructure spending data were collected from annual state budget papers published by the Victorian and NSW State Governments for budget years 1999/2000 to 2015/16 (Victorian Department of Treasury and Finance, 2017; New South Wales Treasury, 2015). These budget papers report spending on establishing and improving infrastructure projects, also known as State Capital Program. Infrastructure investment typically represents 20 to 30 percent of total state government annual budget.

We grouped all funded projects under twelve infrastructure categories, including: public housing; community services (e.g., neighbourhood facilities, aging, disability and home care facilities and homelessness services facilities); education; health; policing and emergency facilities; justice facilities (including court houses and correctional facilities); road and traffic; public transport facilities; amenities (e.g., sports, recreational and cultural facilities); urban development (e.g., urban renewal projects); utilities (electricity, water, sewage and treatment facilities); and, other government projects (such as government offices).

State budget papers indicated the state suburb location for most projects. Thus, each project was geo-referenced to state suburbs. To account for inflation and the time value of money, all historical expenses were compounded to 2015 dollars at an annualised rate of five per cent. We also tested the use of rates of two per cent and seven percent, and the results were not sensitive to these changes.

Differentiated redistribution was analysed by comparing overall expenditure in each infrastructure category in each of the cities. Area-based redistribution was analysed by comparing average annual investment levels in different areas of both cities, adjusted for population. Systemic redistribution was analysed by comparing the degree of centralisation in the funding distribution pattern of each city, as indicated by the proportion of funding allocated to the CBD, and the inner-, middle-, and outer-suburbs.

For analysing both area-based and systemic redistribution, we first constructed a set of nine comparable metropolitan subregions in both cities (Figures 1 and 2, Table 2). These clusters were constructed using geographic, housing and demographic variables based on information from 2016 Census and location-based socio-economic measures, Socio-Economic Index for Areas (SEIFA) (ABS 2018a; ABS 2018b), including: population density, population growth 


\section{Context}

Sydney and Melbourne are Australia's two largest cities, with populations of 5.1 million and 4.8 million respectively as of June 2017, accounting together for about 40 percent of the total national population. They are the capital cities of the states of New South Wales and Victoria and represent the majority of their states' population, 65 and 76 percent respectively (ABS, 2018c).

Each of the metropolises is comprised of about 30 Local Government Areas. In Australia's three-tiered government system, the states are responsible for funding schools, hospitals,

\footnotetext{
${ }^{1}$ We have used the ABS 2016 SEIFA in Sydney and Melbourne to analyse concentration of relative socio-economic disadvantage. Specifically we use the Index of Relative SocioEconomic Disadvantage for Areas, which combines variables such as income, education, employment, occupation, and housing.
} 
conservation and environment, roads, railways and public transport, public works, public housing, community services, sport and recreation, police, prisons and emergency services.

\author{
[Insert Figure 1 here] \\ [Insert Figure 2 here] \\ [Insert Table 2 here]
}

Rising socioeconomic inequalities, coupled with neoliberal planning since the mid-1980s, have transformed the spatial structure of both cities. The inner-city areas of both cities have seen substantial gentrification and densification through apartment development.

Concurrently, from the mid-1980s, residential concentrations of social disadvantage in Sydney and Melbourne have shifted away from the metropolitan cores onto the middle and outer suburbs (Randolph and Tice, 2017), represented in our "Lower Socioeconomic (SES) Suburbs" clusters. However, parallel to the displacement process of disadvantage, approximately 28 percent of Melbourne's total social housing stock and 11 percent of Sydney's total social housing stock remains concentrated in the inner-city, surrounded by relatively affluent neighbourhoods.

Notwithstanding efforts at urban consolidation, metropolitan plans for both Sydney and Melbourne since the late 1980s sought to facilitate urban expansion into peri-urban areas, at the expense of "green wedges" and agricultural land, to meet the demands of a rapidly growing population (McFarland, 2015, p. 167). Concerns have also been raised regarding the "infrastructure deficits" in these emerging outer suburbs, including limited access to hospitals, courts, police, roads, schools, trains and buses (Henderson, 2019).

In Sydney, a stark divide exists between the more affluent north-east, and less advantaged south-west metropolitan regions (see Figure 1), with uneven social development and infrastructure stress (McGuirk and O’Neill, 2002). In Melbourne, smaller clusters of relatively disadvantaged suburbs are dispersed across three different subregions (see Figure 2). Despite evident socio-spatial polarisation, Pawson et al. (2015) argue that, compared with North America, spatial concentrations of disadvantage in Australian cities is moderate. 


\section{Findings}

We now turn to describe the results from our empirical analysis comparing infrastructure investment funding allocation in Melbourne and Sydney between 1999/2000 to 2015/16. Although our conceptual discussion above commenced with area-based redistribution as the starting point for theoretical debates on redistribution, our empirical analysis starts from a description of the overarching infrastructure priorities in each city (systemic redistribution), before attending to the geographical distribution of these infrastructures in different areas (area-based redistribution) and the degree of centralisation in Melbourne's infrastructure networks (systemic redistribution).

\section{Differentiated redistribution: infrastructure investment priorities}

Melbourne attracted a higher proportion of total state infrastructure funding than Sydney. Between 1999/2000 and 2015/16, 74 percent of infrastructure investment of Victoria were assigned to Melbourne, compared to 54 percent of NSW's infrastructure investment allocated to Sydney. Melbourne's share of funding rose further to around 90 percent since 2009. In absolute figures, Sydney received a slightly higher combined amount of infrastructure investment ( $\$ 30.19$ billion, in 2015 dollars) than Melbourne ( $\$ 28.49$ billion). As a proportion of Total Gross State Product, investment levels in both cities were similar. In per-capita terms, however, average per annum investment in Melbourne ( $\$ 574$ per capita per annum) was higher than Sydney (\$491).

Within Sydney and Melbourne, proportional funding levels were similar for most infrastructure categories (Figure 3). In both cities, roads and health infrastructure were among the largest expenditure items, and community services and housing were the smallest. While indicative of governments' infrastructural priorities, differences in expenditure level also reflect the varied costs of different types of infrastructure. Nevertheless, our comparison of investment priorities in Melbourne and Sydney exposed several important differences in the two state governments priorities. State government expenditure on education facilities in Melbourne (\$4827 million) was over two times as high as in Sydney (\$2049 million). In contrast, in Sydney expenditure levels on justice were almost three times as high (\$2021 million compared to $\$ 766$ million in Melbourne). We consider the implications of such priorities for different urban populations in the Discussion section. 
[Insert Figure 3 here]

Differences were apparent also in the infrastructural categories which were prioritised within each metropolitan sub-region, as illustrated in Tables 3 and 4. The implications of subregional differences in infrastructural priorities are elaborated in the following sections.

[Insert Table 3 here]

[Insert Table 4 here]

\section{Area-based redistribution: investment in lower socioeconomic status suburbs}

Significant differences were apparent in the treatment of relatively disadvantaged suburbs in Melbourne and Sydney. In Melbourne, the lower SES suburbs cluster benefited from levels of expenditure 1.13 times the metropolitan average ( $\$ 647.41$ per capita per annum), while investment in the more affluent inner-suburbs cluster was 0.31 times the metropolitan average (\$175.32 per capita per annum). In contrast, in Sydney, funding for the lower SES suburbs (\$362.91 per capita per annum) represented about 74 percent the metropolitan average while the inner-suburbs cluster ( $\$ 578.76$ per capita per annum) benefited from expenditure 1.18 times the metropolitan average.

The lower SES suburbs in Melbourne received relatively high levels of investment in public transport, road and traffic management, and utilities. Expenditure on housing, community services, educational facilities, and health services facilities were slightly above the metropolitan average. This contrasted with Sydney, where expenditure levels were below metropolitan average in nearly every category except health. Within the lower SES suburbs in Sydney, it was the most disadvantaged suburbs (at the bottom IRSD decile) that received the least amount of funding (authors, 2017).

The more affluent inner-suburbs clusters of both cities presented a mirror image: in Melbourne, expenditure was significantly lower than metropolitan average on most categories, and only higher on community services. In Sydney, inner-suburbs expenditure 
was higher on most categories except housing, policing and emergency services, justice, utilities, urban development, and others. While Melbourne's selective high schools were mainly concentrated in the CBD, Sydney's selective high schools were mainly concentrated in the inner-suburbs cluster.

\section{Systemic redistribution: centralised investment}

Infrastructure investment by state governments in Australia has "always favoured the core of metropolitan primates at the expense of proliferating suburbs" (Badcock, 1984, pp.251-2). Our analysis demonstrates that while centralisation remains a primary characteristic of infrastructure funding distribution in both Sydney and Melbourne, it has been more extreme in the former.

Infrastructure investment in Sydney CBD was approximately 48 times, and in Melbourne CBD 19 times, their respective metropolitan averages. In both absolute terms, average annual per-capita infrastructure investment in Sydney CBD was $\$ 23,605$ compared to $\$ 10,893$ in Melbourne.

Importantly, services and infrastructure in the CBD cater not only to local residents, but also those who work in the $\mathrm{CBD}$, commute through the $\mathrm{CBD}$ to get elsewhere, or visit the $\mathrm{CBD}$ for leisure. But even when including in the calculation of per capita investment not only the residential population, but also workers and visitors to the $\mathrm{CBD}$, levels of investment in Sydney's CBD remain well above the metropolitan average. With an estimated 610,000 visitors and students on any given day (City of Sydney, 2015), average annual per capita investment in Sydney's CBD is $\$ 850$, still nearly double the metropolitan average of $\$ 490$. In Melbourne, approximately 911,000 people visited the CBD on an average weekday in 2016 (City of Melbourne, 2017). When including the visiting population, average annual per capital investment in Melbourne CBD was only \$403, well below the metropolitan average of $\$ 574$.

In both Sydney and Melbourne, the most centralised infrastructures were urban development, recreational amenities, public transport, policing, utilities, justice and "other" (primarily government offices). Investment in roads and housing was less extremely centralised, although still several times the metropolitan average. Investments in community and health services were the least centralised. 
The centralisation of expenditure in Sydney and Melbourne was also apparent in investment levels in their inner-city clusters, which were respectively 1.8 and 1.51 higher than the metropolitan average. There were differences in the types of categories funded in the innersuburbs cluster of each city. Expenditure on educational facilities and urban development was higher than average in Sydney, yet lower than average in Melbourne. Investment in housing and emergency services was higher in Sydney, while investment in health and community services was higher in Melbourne's inner-suburbs.

The centralised pattern of infrastructure investment was also reflected in lower levels of investment in the middle-ring suburbs, the largest clusters in both Melbourne and Sydney. In both cities, infrastructure expenditure in the middle-ring clusters was below the metropolitan average, albeit much lower in Sydney (0.45 compared to 0.64 in Melbourne). In both cities' middle-ring suburbs, expenditure levels were particularly low in public transport, roads, recreation amenities and community services. Low investment in public transport is particularly problematic, since it exacerbates low-income households' poor access to other kinds of infrastructure and services. A significant contrast between the two cities' middlering related to education and health- where expenditure in Melbourne was above metropolitan average, and in Sydney well below.

Sydney's more extremely centralised pattern was also reflected in a lower share of funding allocated to the outer suburbs. In Sydney, expenditure in the outer suburbs was nearly half the metropolitan average, and was lower than the metropolitan average in all infrastructure categories except roads and K12 educational facilities. In contrast, expenditure in the outer suburbs of Melbourne was slightly higher than the metropolitan average, and was particularly high in the categories of urban development, policing, utilities, selective schools, and roads. In both cities, low levels of expenditure on public transport in the outer-suburbs reiterate concerns about vulnerability associated with car dependency (Dodson and Sipe, 2008).

\section{Discussion}

The findings illustrate the potential of an area-based mode of analysing redistribution in exposing discrimination against specific urban areas in distribution of funding for infrastructure and services, albeit also the limitations of this approach. In this study we were able to reveal the sharp contrast between Melbourne and Sydney. Melbourne's redistributive approach benefitting clusters of the city's most disadvantaged areas was similar to Bramley et 
al's (1998) findings in the UK. In contrast, Sydney presented a pattern of maldistribution, whereby the city's cluster of lower SES suburbs was relatively deprived in funding allocation. Area-based redistribution could also be criticised as promoting state-led gentrification, and as such potentially harmful rather than beneficial for disadvantaged groups at risk of displacement. Indeed, the gentrification of both cities' inner-suburbs since the 1980s paralleled a highly centralised pattern of investment, and led to massive displacement of disadvantaged households (Badcock, 1984; Gleeson and Randolph, 2002). However, despite significant infrastructure investment, we have not identified similar patterns of gentrification and displacement in Melbourne's lower SES suburbs during the period examine in our study.

Attributing spatial advantage or disadvantage to an area masks uneven distribution of outcomes among its residents. A differentiated mode of analysing is necessary to reveal inequalities in the treatment of different populations rather than areas. Once again, our analysis revealed significant differences in the infrastructural priorities of both cities: education in Melbourne, roads and justice facilities in Sydney.

The question of which populations might benefit or be harmed by such infrastructural priorities requires further investigation. For example, education outcomes are highly differentiated by socioeconomic status, indigeneity and cultural background with a generally regressive pattern of higher educational attainment among more advantaged populations. Indeed, despite higher investment in education infrastructure, disadvantage in education outcomes persists in the suburbs of Laverton, Campbellfield-Coolaroo and Dandenong (Bankwest Curtin Economics Centre, 2017), which are located within our lower SES suburbs cluster. Nevertheless, although educational outcomes in these areas were the poorest in Victoria, by national standards they scored "reasonably well". Also, the gap between Indigenous and non-Indigenous students was lowest in Victoria (Bankwest Curtin Economics Centre, 2017). This might suggest that both area-based and differentiated redistribution in education in Melbourne has contributed to lower levels of education disadvantage compared to other states.

In contrast, the prioritisation of expenditure on justice facilities in Sydney can be interpreted as maldistribution, associated with negative outcomes especially for Indigenous people, and those with cognitive or psycho-social disability. Indigenous people comprise 24 percent of the prisoner population in NSW, compared to 9 percent in Victoria. Between 2001-2015, the 
number of indigenous Australians in NSW prisons has more than doubled. Likewise, people with psychosocial or cognitive disability are grossly overrepresented in the justice system, in both NSW and Victoria (Mental Health Commission of New South Wales, 2017; Victorian Ombudsman, 2015).

The remedy for such differentiated maldistribution can be described in terms of "Justice Reinvestment", defined by Schwartz et al. (2017, p. 1) as a focus on "redirecting criminal justice spending into programs which are likely to achieve reductions in offending and imprisonment", including adequate investment in welfare, health and disability support infrastructures and services.

Applying a systemic redistribution mode of analysis, our analysis pointed to disproportionate investment of infrastructure funding in both cities' CBDs, but twice as much in Sydney. The centralisation of infrastructure investment, perpetuates maldistribution for lower-income households, which are increasingly concentrated in the middle and outer suburbs with more limited access to these centralised services and facilities (Gleeson and Randolph, 2002, pp. 103-4). The higher proportion of social housing stock maintained in Melbourne's infrastructure-rich inner-city (28 percent compared to 11 percent in Sydney), represents a very partial response to such systemic maldistribution. From a gender perspective, a highly centralised urban system is associated with gender inequality (Sandercock and Forsyth, 1999). Beyond centralisation, further investigation is required to understand other systemic characteristics of urban infrastructural networks, such as integration between transport, housing and other services.

In recent years, a number of major planning initiatives in both Sydney and Melbourne seek to promote metropolitan decentralisation, and as such can be understood as attempts at systemic redistribution. These include plans for a second Sydney CBD in Parramatta, a second Sydney airport in Badgery Creek, and a suburban ring railway line in Melbourne. Further research will be necessary to investigate the distributive effects of such initiatives.

\section{Conclusion}

Redistribution is not a remedy to all urban injustices. We concur with Marcuse's (2009, p. 92) claim that distributive justice is a "necessary but not sufficient" element of the just city, alongside other equally important elements, including recognition (Fraser, 1995), conviviality 
(Fincher and Iveson, 2008), democracy (Fainstein, 2010), and the commons (Marcuse, 2009). Nevertheless, a revitalised redistribution agenda is necessary to redress some of the urban injustices reinforced by neoliberalism. Towards this end, in this paper we proposed a reconceptualisation of redistribution in public urban infrastructure, that builds on the Ralwsian-Keynesian-Fordist notion of redistribution as a starting point, but also addresses its shortfalls and critiques by distinguishing between five modes through which redistribution can be understood and practically pursued.

The comparison between Melbourne and Sydney - and the consistency of results across three modes of analysis - points to the interconnectedness of area-based, systemic and differentiated modes of redistribution or maldistribution. A more centralised mode of investment (systemic) reinforced area-based maldistribution in Sydney. In Melbourne, the prioritisation of education infrastructure (differentiated), and specifically within disadvantaged suburbs (area-based), may have helped reduce (but not to fully close) the gap in educational attainment. But it is dangerous to assume a straightforward causal relationship between the three modes of redistribution, and critical attention is necessary in future studies to identify not only consistency, but also potential contradictions. A fuller understanding of distributive patterns must also incorporate analysis of structural and relational modes of redistribution.

Analysis of structural redistribution - how decisions about funding allocation and delivery are being made - is necessary to understand why such differences are apparent between Sydney and Melbourne, or other cities. This requires analyses at different scales: investigating how funding allocation systems operate and the power relations within them; qualitative interviews with multiple stakeholders involved in negotiation of funding priorities; and, case studies involving negotiations surrounding specific infrastructure projects.

Analysis of relational redistribution is necessary to understand the impacts of redistribution in its varied modes on social relations and change. This requires qualitative ethnographic insight into the everyday lived experiences of infrastructures, with a particular focus on the characteristics of infrastructural settings that support or inhibit more convivial encounters across social differences (Fincher and Iveson, 2008).

\section{References}


Australian Bureau of Statistics (2018a) Census of Population and Housing. Canberra: Commonwealth of Australia.

Australian Bureau of Statistics (2018b) Socio-Economic Indexes for Areas (SEIFA).

Canberra: Commonwealth of Australia.

Australian Bureau of Statistics (2018c) Regional Population Growth, Australia, 2016-17. http://www.abs.gov.au/ausstats/abs@.nsf/mf/3218.0 (Accessed 19 February 2019).

Badcock B (1984) Unfairly structured cities. London: Blackwell.

Bankwest Curtin Economics Centre (2017) Educate Australia Fair? Education Inequality in Australia. https://bcec.edu.au/assets/099068 BCEC-Educate-Australia-Fair-EducationInequality-in-Australia WEB.pdf (Accessed 12 February 2019).

Bowles S and Fong CM (2012) The new economics of inequality and redistribution. Cambridge: Cambridge University Press.

Bramley G, Evans M and Atkins J (1998) Where Does Public Spending Go? Pilot Study to Analyse the Flows of Public Expenditure into Local Areas. London: DETR.

City of Melbourne (2017) Daily population Estimates and Forecasts (2017 Update). https://www.melbourne.vic.gov.au/sitecollectiondocuments/daily-population-estimates-andforecasts-report-2017.pdf (Accessed 4 Feb 2019).

City of Sydney (2015) Tourism. https://www.cityofsydney.nsw.gov.au/business/build-yourskills-and-knowledge/business-research-and-data/business-in-your-sector/keyindustries/tourism (Accessed 4 Feb 2019).

Davidson M (2018) Participatory budgeting, austerity and institutions of democracy: The case of Vallejo, California. City 22 (4): 551-567.

Dear M (1992) Understanding and overcoming the NIMBY syndrome. Journal of the American Planning Association 58 (3): 288-300.

DeFillipis J (2009) On globalization, competition, and economic justice in cities. In: Marcuse P, Connolly J, Novy J, Olivo I, Potter C and Steil J (eds) Searching for the just city: Debates in urban theory and practice. London: Routeledge, pp. 144-158.

Dodson J and Sipe N (2008) Shocking the suburbs: urban location, homeownership and oil vulnerability in the Australian city. Housing Studies 23 (3): 377-401. 
Enright, T. (2019). Transit justice as spatial justice: learning from activists. Mobilities, 14(5): 665-680.

Fainstein SS (2010) The just city. Ithaca, N.Y.: Cornell University Press.

Fincher R and Iveson K (2008) Planning and Diversity in the City: Redistribution, Recognition and Encounter. New York: Palgrave MacMillan.

Fraser N (1995) From redistribution to recognition? Dilemmas of justice in a 'post-socialist' age. New left review 212: 68.

Gilroy P (2006) Multiculture in times of war: an inaugural lecture given at the London School of Economics. Critical Quarterly 48 (4): 27-45.

Gleeson,B and Randolph B (2002) 'Social disadvantage and planning in the Sydney context', Urban Policy and Research, Vol. 20 (1): 101-107.

Graham S (2010) When Infrastructures Fail 1. In S Graham (ed) Disrupted cities: When infrastructure fails. London: Routledge. pp. 13-59

Graham S and Marvin S (2002) Splintering urbanism: networked infrastructures, technological mobilities and the urban condition. London: Routledge.

Harvey D (1973) Social Justice and the City. Baltimore: Johns Hopkins University Press. Hayden D (1980) What would a non-sexist city be like? Speculations on housing, urban design, and human work. Signs: Journal of Women in Culture and Society 5 (3): 170-187. Henderson SR (2019) Outer metropolitan areas and infrastructure deficits: Policy dynamics on the edge of Melbourne, Australia. Cities 90: 24-31.

Iveson K, Fincher R and Gleeson B (2018) Iris Marion Young and urban geographies of difference. Geografiska Annaler: Series B, Human Geography 100 (3): 287-293.

Jessop B (2002) The Future of the Capitalist State. Oxford: Polity Press.

Lefebvre, H. 1968. Le droit a la ville. Paris: Anthropos.

Levy F, Meltsner AJ and Wildavsky AB (1974) Urban outcomes: Schools, streets, and libraries. Berkeley: University of California Press. 
Marcuse P (2009) From justice planning to commons planning. In: Marcuse P, Connolly J, Novy J, Olivo I, Potter C and Steil J (eds) Searching for the just city: Debates in urban theory and practice. London: Routeledge, pp. 111-122.

McCrudden C (2004) Using public procurement to achieve social outcomes. Natural resources forum 28 (4): 257-267).

McFarland P (2015) The peri-urban land-use planning tangle: An Australian perspective. International Planning Studies 20 (3): 161-179.

McGuirk P and O’Neill P (2002) Planning a Prosperous Sydney: the Challenges of Planning Urban Development in The New Urban Context, Australian Geographer 33 (3): 301-316.

Mental Health Commission of New South Wales (2017) Towards a just system: Mental illness and cognitive impairment in the criminal justice system.

https:/nswmentalhealthcommission.com.au/sites/default/files/documents/justice_paper_final web.pdf

Mills CW (2013) Retrieving Rawls for racial justice? A critique of Tommie Shelby. Critical Philosophy of Race 1(1):1-27.

New South Wales Treasury (2015) NSW Budget Papers.

http://www.treasury.nsw.gov.au/Publications_Page/Budget_Papers (Accessed 5 July 2017).

Pawson H, Davison G, and Wiesel I (2012) Addressing concentrations of disadvantage:

policy, practice and literature review, AHURI Final Report No.190. Melbourne: Australian Housing and Urban Research Institute.

Pereira RH, Schwanen T, and Banister D (2017) Distributive justice and equity in transportation. Transport reviews 37(2): 170-191.

Randolph B and Tice A (2017) Relocating disadvantage in five Australian cities: sociospatial polarisation under neo-liberalism. Urban policy and research 35 (2): 103-121.

Rawls J (1971) A theory of Justice. Cambridge, MA: Harvard University Press.

Roberts DJ and Catungal JP (2018) Neoliberalizing social justice in infrastructure revitalization planning: Analyzing Toronto's More Moss Park project in its early stages. Annals of the American Association of Geographers 108 (2): 454-462. 
Sandercock L and Forsyth A (1992) A gender agenda: new directions for planning theory. Journal of the American Planning Association 58 (1): 49-59.

Schwartz M, Brown D and Cunneen C (2017) Justice Reinvestment, Indigenous Justice Clearinghouse, Brief 21, https:/www.indigenousjustice.gov.au/wpcontent/uploads/mp/files/publications/files/rb21-justice-reinvestment-schwartz-et-al-2017-ijcwebv2.pdf

Victorian Department of Treasury and Finance (2017) State Budget. http:// www.dtf.vic.gov.au/State-Budget/Previous-budgets (Accessed 5 July 2017).

Victorian Ombudsman (2015) Investigation into the rehabilitation and reintegration of prisoners in Victoria. https://www.ombudsman.vic.gov.au/getattachment/5188692a-35b6411f-907e-3e7704f45e17 (Accessed 19 February 2019).

Wiesel I, Liu F and Buckle C (2018) Locational disadvantage and the spatial distribution of government expenditure on urban infrastructure and services in metropolitan Sydney (19882015). Geographical Research 56 (3): 285-297.

Young IM (1990) Justice and the Politics of Difference. Princeton: Princeton University Press. 
Table 1. Five Modes of Redistribution

\begin{tabular}{|c|c|c|c|c|}
\hline $\begin{array}{l}\text { Modes of } \\
\text { redistribution }\end{array}$ & Inspirations & $\begin{array}{l}\text { Conception of urban } \\
\text { space and infrastructures }\end{array}$ & Research questions & Measures \\
\hline Area-based & $\begin{array}{l}\text { Liberal } \\
\text { distributive } \\
\text { justice (Rawls, } \\
\text { 1971) }\end{array}$ & $\begin{array}{l}\text { Space as container of } \\
\text { goods and harms unevenly } \\
\text { distributed; proximity as a } \\
\text { key determinant of access; } \\
\text { infrastructures as a material } \\
\text { 'good' or 'externality' }\end{array}$ & $\begin{array}{l}\text { Which areas receive a } \\
\text { superior bundle of } \\
\text { services, as added real } \\
\text { income to residents? }\end{array}$ & \$ per area \\
\hline Differentiated & $\begin{array}{l}\text { Affirmative } \\
\text { recognition } \\
\text { (Fraser, 1995) }\end{array}$ & $\begin{array}{l}\text { Space as a site of conflict } \\
\text { across predetermined lines } \\
\text { of social differences } \\
\text { (gender, race, ability, age); } \\
\text { Access and benefit from } \\
\text { infrastructures determined } \\
\text { primarily by social } \\
\text { differences (secondspace) }\end{array}$ & $\begin{array}{l}\text { What kinds of } \\
\text { infrastructures and } \\
\text { services are prioritised } \\
\text { over others, and which } \\
\text { social groups benefit or } \\
\text { are harmed by these? }\end{array}$ & $\begin{array}{l}\text { \$ per } \\
\text { infrastructure } \\
\text { category } \\
\text { Infrastructure } \\
\text { usage, } \\
\text { benefits and } \\
\text { harms by } \\
\text { different } \\
\text { populations }\end{array}$ \\
\hline Systemic & $\begin{array}{l}\text { Critical } \\
\text { networked } \\
\text { urbanism } \\
\text { (Graham and } \\
\text { Marvin, 2002) }\end{array}$ & $\begin{array}{l}\text { Infrastructure networks as } \\
\text { inter-connected systems } \\
\text { which produce differential } \\
\text { outcomes for different } \\
\text { populations }\end{array}$ & $\begin{array}{l}\text { What kind of network is } \\
\text { produced by allocation } \\
\text { decisions, and who } \\
\text { benefits from it? }\end{array}$ & $\begin{array}{l}\text { Measures of } \\
\text { centralisation, } \\
\text { density, and } \\
\text { integration in } \\
\text { infrastructure } \\
\text { network }\end{array}$ \\
\hline Structural & $\begin{array}{l}\text { Transformative } \\
\text { redistribution } \\
\text { (Fraser, 1995); } \\
\text { Right to the } \\
\text { city (Lefebvre, } \\
\text { 1968); }\end{array}$ & $\begin{array}{l}\text { Infrastructure planning and } \\
\text { delivery systems as deeply } \\
\text { connected to wider political } \\
\text { structures (capitalism, } \\
\text { settler-colonialism, } \\
\text { patriarchy, etc.) }\end{array}$ & $\begin{array}{l}\text { What are the systems } \\
\text { through which } \\
\text { infrastructures are } \\
\text { spatially allocated? } \\
\text { Who controls these } \\
\text { systems? } \\
\text { How might these } \\
\text { systems be } \\
\text { transformed? }\end{array}$ & $\begin{array}{l}\text { Qualitative } \\
\text { analysis of } \\
\text { infrastructure } \\
\text { planning and } \\
\text { delivery } \\
\text { processes, } \\
\text { and grassroot } \\
\text { initiatives to } \\
\text { alter these }\end{array}$ \\
\hline Relational & $\begin{array}{l}\text { Conviviality; } \\
\text { (Gilroy, 2006; } \\
\text { Fincher and } \\
\text { Iveson, 2008) }\end{array}$ & $\begin{array}{l}\text { Urban spaces and } \\
\text { infrastructure as sites of } \\
\text { everyday encounter where } \\
\text { a culture of conviviality can } \\
\text { be developed and practiced }\end{array}$ & $\begin{array}{l}\text { What types of } \\
\text { infrastructure might } \\
\text { support convivial } \\
\text { encounter across social } \\
\text { difference? Where and } \\
\text { how should such } \\
\text { infrastructures be } \\
\text { delivered? }\end{array}$ & $\begin{array}{l}\text { Qualitative } \\
\text { analysis of } \\
\text { everyday } \\
\text { social } \\
\text { relations in } \\
\text { infrastructural } \\
\text { settings }\end{array}$ \\
\hline
\end{tabular}

Source: Authors 
Table 2. Sydney and Melbourne Clusters, Selected Characteristics

\begin{tabular}{|c|c|c|c|c|c|c|}
\hline & CBD & Inner city & $\begin{array}{c}\text { Inner } \\
\text { suburbs }\end{array}$ & $\begin{array}{l}\text { Middle } \\
\text { suburbs }\end{array}$ & $\begin{array}{l}\text { Outer } \\
\text { suburbs }\end{array}$ & $\begin{array}{r}\text { Emer } \\
\text { subs }\end{array}$ \\
\hline Suburb distance to CBD, Mean, km & n.a. & 4.30 & 7.25 & 14.04 & 29.11 & \\
\hline \multicolumn{7}{|l|}{ Average residential density, per sq $\mathrm{km}$} \\
\hline Melbourne (2001) & 1905.74 & 3135.44 & 2924.46 & 2086.55 & 981.74 & 2 \\
\hline Melbourne (2016) & 6701.22 & 4282.35 & 3481.07 & 2387.49 & 1130.68 & 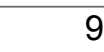 \\
\hline Sydney (2001) & 2204.65 & 5818.36 & 4066.67 & 1817.17 & 1213.98 & 6 \\
\hline Sydney (2016) & 5320.35 & 9548.74 & 4944.10 & 2156.06 & 1425.17 & 6 \\
\hline \multicolumn{7}{|c|}{ Average annual population growth rate, $\%$} \\
\hline Melbourne & 8.74 & 2.1 & 1.17 & 0.90 & 0.95 & \\
\hline Sydney & 6.05 & 3.36 & 1.31 & 1.15 & 1.07 & \\
\hline \multicolumn{7}{|l|}{$\%$ of apartments within cluster, 2016} \\
\hline Melbourne & 81.35 & 55.36 & 26.82 & 9.53 & 2.80 & \\
\hline Sydney & 96.93 & 73.12 & 51.83 & 24.84 & 1.55 & \\
\hline \multicolumn{7}{|c|}{ Social housing as percent of housing stock } \\
\hline Melbourne & 1.50 & 7.09 & 2.22 & 1.92 & 1.38 & \\
\hline Sydney & 1.06 & 7.62 & 3.15 & 3.56 & 2.81 & \\
\hline \multicolumn{7}{|c|}{ Indexes Relative Socio-economic Disadvantage, Mean } \\
\hline Melbourne (2001) & 1081 & 1029 & 1066 & 1058 & 1046 & \\
\hline Melbourne (2016) & 1066 & 1036 & 1074 & 1056 & 1049 & \\
\hline Sydney (2001) & 955 & 1062 & 1066 & 1071 & 1004 & \\
\hline Sydney (2016) & 1086 & 1047 & 1064 & 1075 & 1032 & \\
\hline
\end{tabular}

Note: NSW Central Coast Region were excluded from this analysis.

Peri-urban areas and non-residential suburbs were excluded from the Metropolitan average.

Social housing includes state public housing dwellings, community housing groups, cooperative housing, Source: Based on ABS customised Census data 
Table 3. 1999/2000-2015/16 state infrastructure expenditure by category, by cluster in Melbourne

\begin{tabular}{|c|c|c|c|c|c|c|}
\hline & CBD & Inner city & $\begin{array}{l}\text { Inner } \\
\text { suburbs }\end{array}$ & $\begin{array}{l}\text { Middle } \\
\text { suburbs }\end{array}$ & $\begin{array}{l}\text { Outer } \\
\text { suburbs }\end{array}$ & $\begin{array}{l}\text { Emerging } \\
\text { suburbs }\end{array}$ \\
\hline Housing & 100.25 & 28.54 & - & 3.69 & 6.49 & 3.57 \\
\hline $\begin{array}{l}\text { Community Service } \\
\text { facilities }\end{array}$ & - & 20.59 & 23.33 & 7.02 & 1.61 & - \\
\hline Educational facilities & 400.72 & 57.55 & 41.81 & 111.20 & 61.90 & 175.18 \\
\hline$-\mathrm{K} 12$ & 2.55 & 24.65 & 24.78 & 61.97 & 49.79 & 150.16 \\
\hline - Selective schools & 115.86 & - & - & 1.94 & - & 8.33 \\
\hline $\begin{array}{l}\text { Health Service } \\
\text { facilities }\end{array}$ & 154.77 & 386.97 & 25.13 & 126.77 & 31.56 & 11.34 \\
\hline $\begin{array}{l}\text { Policing, fire \& } \\
\text { emergency }\end{array}$ & 272.44 & 36.72 & 18.36 & 10.02 & 17.08 & 38.17 \\
\hline Justice facilities & 945.88 & 15.60 & 2.35 & 6.45 & - & - \\
\hline Public transport & $1,344.11$ & 59.23 & 4.62 & 18.25 & 9.47 & 37.85 \\
\hline $\begin{array}{l}\text { Road and traffic } \\
\text { management }\end{array}$ & 348.82 & 52.12 & 44.87 & 34.52 & 103.78 & 269.08 \\
\hline Utilities & 712.59 & 29.93 & 14.44 & 32.59 & 32.42 & 85.96 \\
\hline $\begin{array}{l}\text { Recreational } \\
\text { facilities, amenities }\end{array}$ & $4,016.22$ & 151.24 & 0.42 & 16.11 & 1.93 & - \\
\hline Urban development & $1,096.30$ & 6.90 & - & - & 56.79 & - \\
\hline Others & $1,501.71$ & 19.34 & - & 0.18 & 0.16 & - \\
\hline Total & $10,893.81$ & 864.73 & 175.32 & 366.80 & 323.17 & 621.15 \\
\hline
\end{tabular}

Notes: in 2015 dollar, \$, per capita per annum; Source: Authors 
Table 4. 1999/2000-2015/16 state infrastructure expenditure by category, by cluster in Sydney

\begin{tabular}{|c|c|c|c|c|c|c|c|}
\hline & \multicolumn{2}{|c|}{ CBD } & \multirow[b]{2}{*}{ Inner city } & \multirow[b]{2}{*}{$\begin{array}{l}\text { Inner } \\
\text { suburbs }\end{array}$} & \multirow[b]{2}{*}{$\begin{array}{l}\text { Middle } \\
\text { suburbs }\end{array}$} & \multirow[b]{2}{*}{$\begin{array}{l}\text { Outer } \\
\text { suburbs }\end{array}$} & \multirow[b]{2}{*}{$\begin{array}{c}\text { Emerging } \\
\text { suburbs }\end{array}$} \\
\hline & Sydney & Parramatta & & & & & \\
\hline Housing & 18.84 & - & 135.14 & 1.98 & - & - & - \\
\hline $\begin{array}{l}\text { Community Service } \\
\text { facilities }\end{array}$ & 9.23 & - & 5.50 & 13.88 & 1.96 & - & \\
\hline Educational facilities & $1,046.36$ & - & 69.11 & 27.90 & 17.69 & 20.31 & 83.69 \\
\hline$-K 12$ & - & - & 13.41 & 10.78 & 12.07 & 19.34 & 83.69 \\
\hline - Selective schools & - & - & 3.22 & 11.54 & 2.21 & 0.31 & - \\
\hline $\begin{array}{l}\text { Health Service } \\
\text { facilities }\end{array}$ & 14.37 & 221.17 & 190.29 & 187.95 & 56.42 & 2.31 & - \\
\hline $\begin{array}{l}\text { Policing, fire \& } \\
\text { emergency }\end{array}$ & 739.91 & $1,115.26$ & 85.69 & 6.55 & 2.82 & 5.87 & 0.23 \\
\hline Justice facilities & $1,111.86$ & $1,632.60$ & 25.37 & 1.82 & 23.84 & 1.97 & 44.91 \\
\hline Public transport & $4,384.81$ & 427.62 & 91.24 & 57.26 & 19.04 & 30.99 & 48.85 \\
\hline $\begin{array}{l}\text { Road and traffic } \\
\text { management }\end{array}$ & 809.47 & 482.19 & 24.22 & 175.68 & 46.05 & 24.23 & 430.68 \\
\hline Utilities & 880.83 & 38.31 & 13.35 & 11.75 & 39.78 & - & 23.99 \\
\hline $\begin{array}{l}\text { Recreational facilities, } \\
\text { amenities }\end{array}$ & $4,658.19$ & 196.47 & 89.45 & 53.68 & 9.05 & 9.68 & 2.27 \\
\hline Urban development & $4,159.44$ & - & 135.50 & 18.76 & - & - & - \\
\hline Others & $5,772.46$ & 990.68 & 17.41 & 21.55 & 4.41 & 0.59 & 1.15 \\
\hline Total & $23,605.78$ & $5,104.31$ & 882.28 & 578.76 & 221.06 & 95.94 & 635.77 \\
\hline
\end{tabular}

Notes: in 2015 dollar, \$, per capita per annum; Source: Authors 


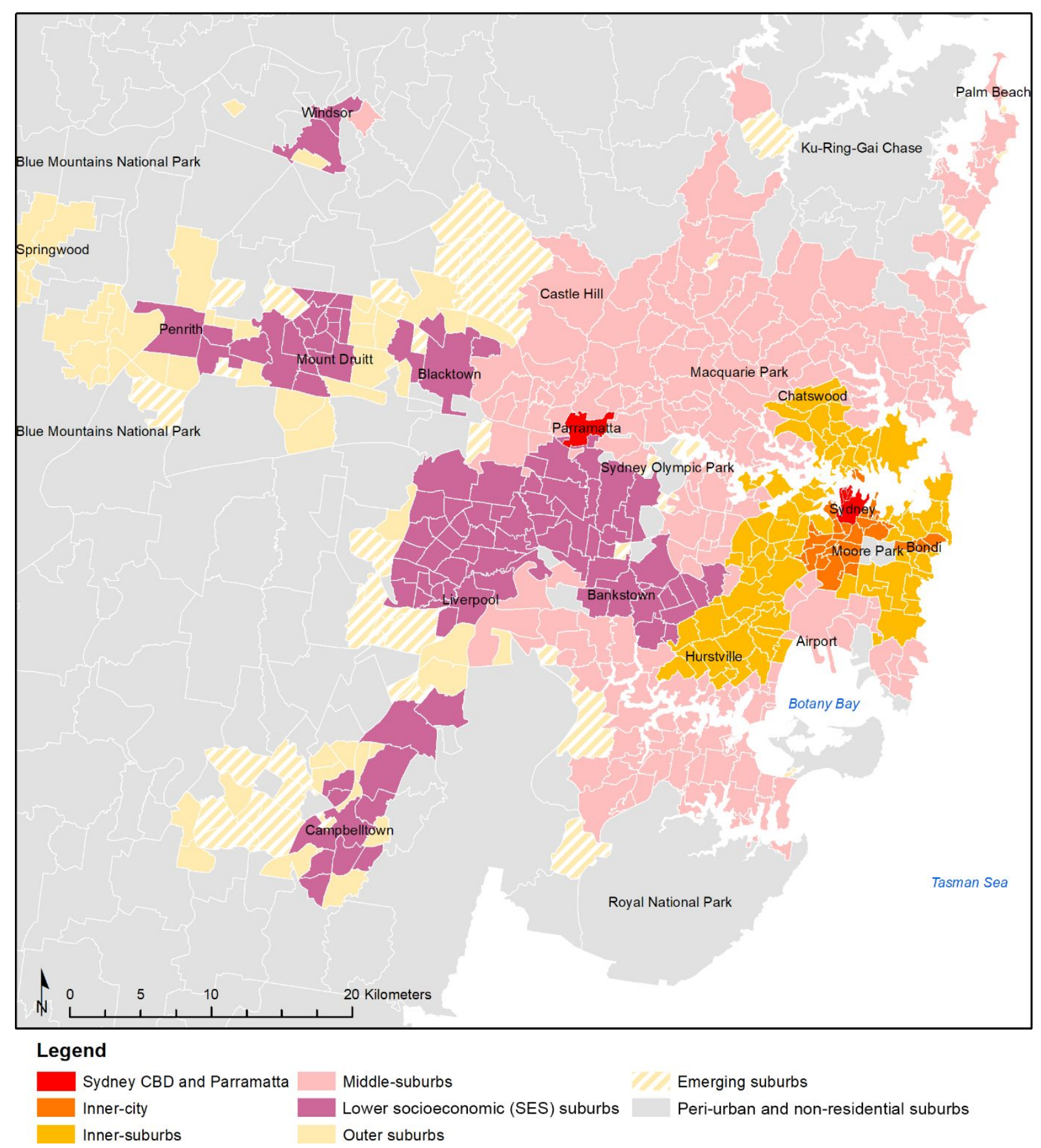

Figure 1. Sydney Metropolitan Clusters 


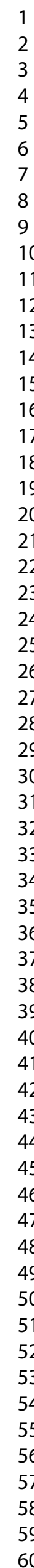

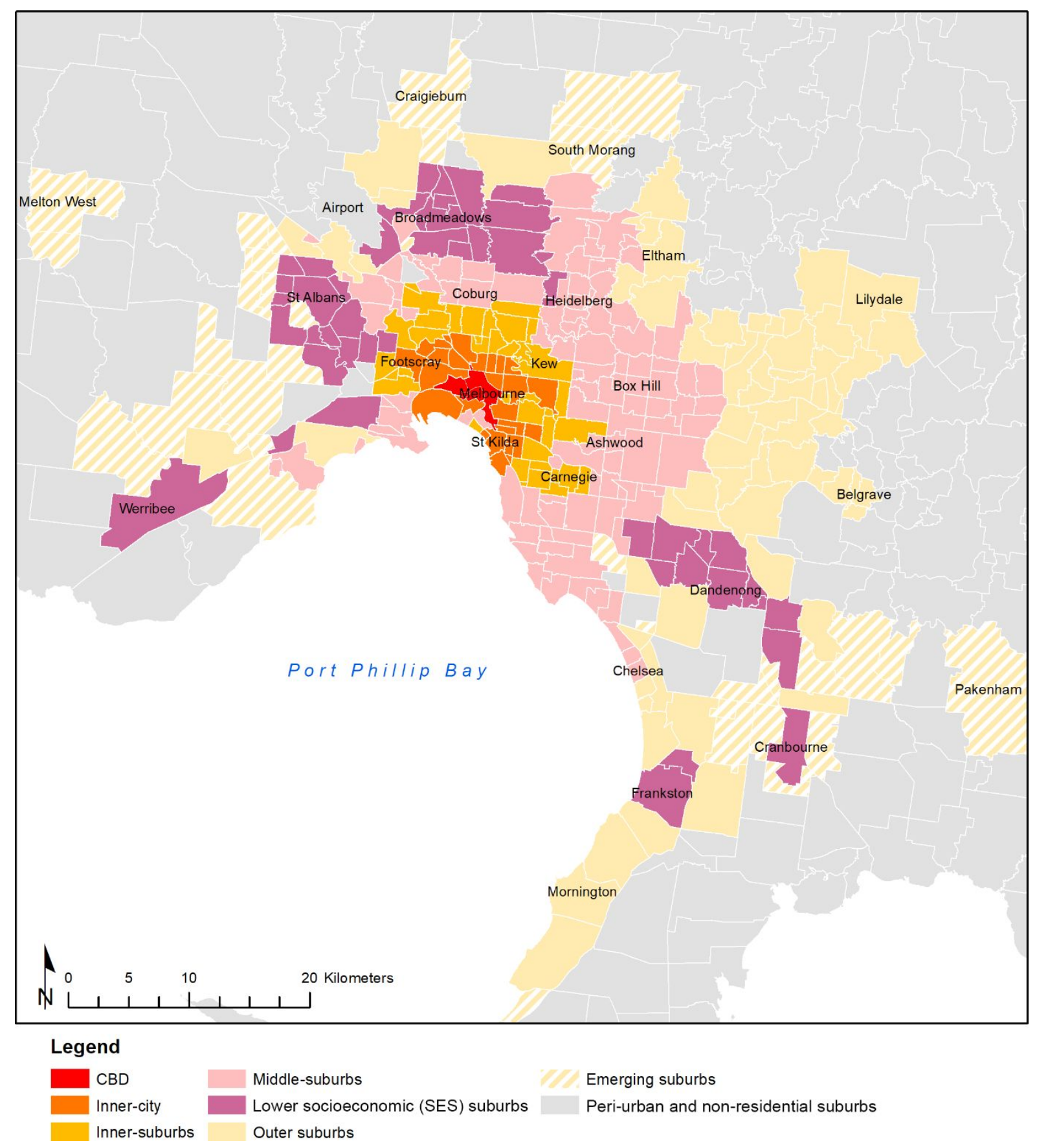

Figure 2. Melbourne Metropolitan Clusters 


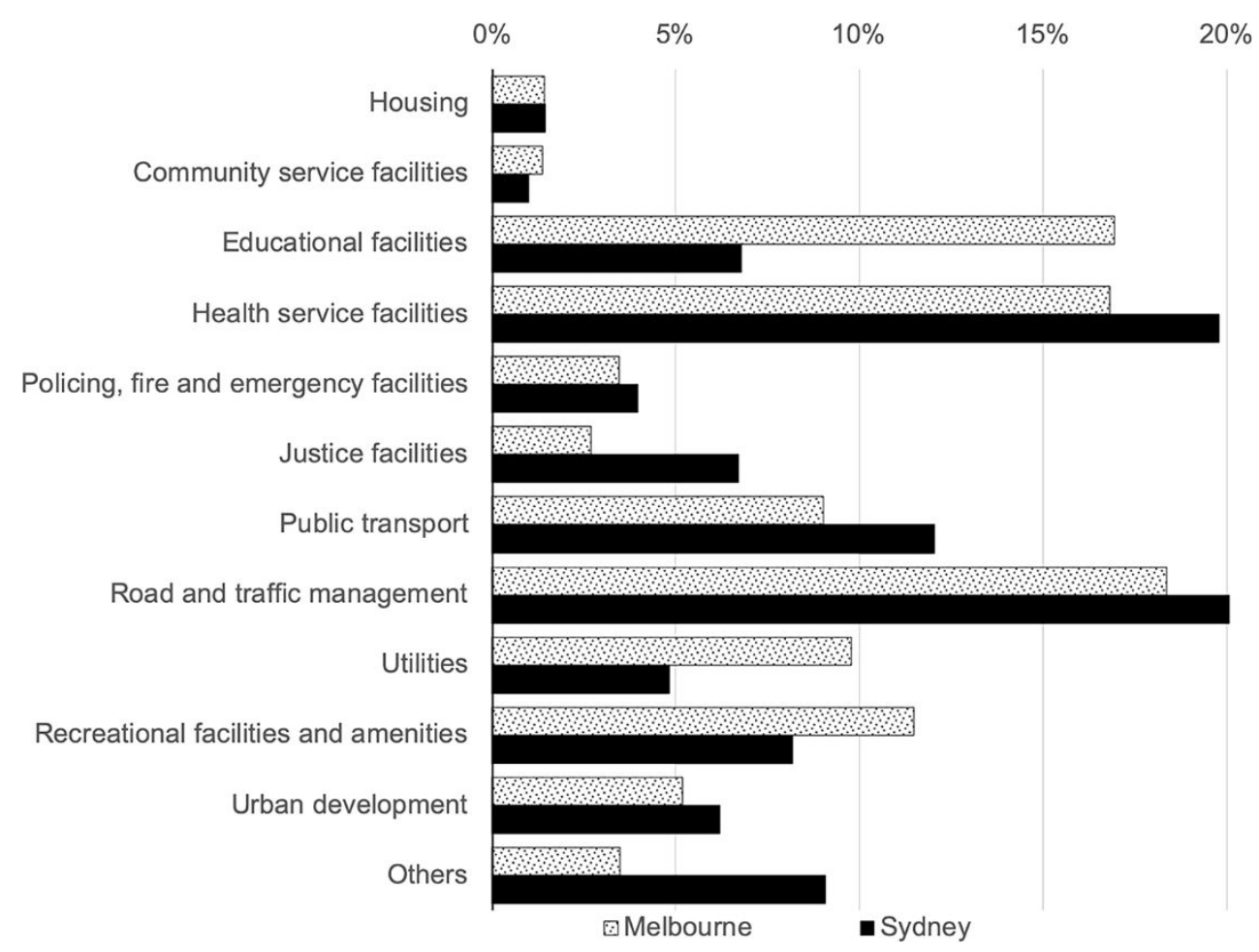

Figure 3. Investment priorities in Sydney and Melbourne, by \% of total expenditure, $1999 / 2000-2015 / 16$ 